\title{
Sürdürülebilir Afet Yönetiminde Atık Yönetimi
}

\author{
Ülker Aslı Güler ${ }^{1, *}$ \\ ${ }^{1}$ Cumhuriyet Üniversitesi, Mühendislik Fakültesi, Çevre Mühendisliği Bölümü, 58140, Sivas.
}

\section{Özet}

Afetler dünya genelinde önemli hasarlara neden olmaktadırlar. Bu hasarlar; yaşamın normalleşmesi, yeniden yapılanma ve genel atık toplama ve bertaraf süreçlerinde çevresel ve ekonomik bir yüke neden olmaktadır. Bir afetin büyüklüğ̈̈, var olan tehlike ve zarar görebilirlik kavramlarl ile ilgilidir. Zarar görebilirlik ifadesine etki eden önemli faktörlerden biri de çevre kavramıdır. Hızlı nüfus artışı, düzensiz şehirleşme, doğal çevrenin tahribi, küresel iklim değişiklikleri, öngörülemeyen tehlike ve riskler afetlerin büyüklüğünü etkilemekte ve toplumlarda önemli mağduriyetler yaratmaktadırlar. Ayrıca, meydana gelen afetler, şiddetlerine bağlı olarak fazla miktarda enkaz ve atı oluşturabilirler. Sürdürülebilir bir afet yönetim sistemi tüm bu olası afetlerin zararlarını azaltabilmek için uygulanmalıdır. Afet yönetim sistemi içerisinde atı yönetimi önemli bir yer tutmaktadır. Afetler sonucu oluşan atıklar, bu atıkların bertaraf seçenekleri ve uygulanan bertaraf yöntemleri çevre ve halk sağllğı açısından oldukça önemlidir. Afet atık yönetimi stratejileri; atık planlama ve kontrolü, atık bileşimi ve miktarı, atıkların toplanması ve bertaraf seçenekleri, çevre ve halk sağlĭg yasal mevzuatlar çerçevesinde değerlendirilmektedir. Iyi yönetilemeyen sistem sonucu ortaya çıkan atıklar, çevre ve halk sağllğı sorunlarına neden olabilmektedir. Bu derleme çalışmasında, literatüre dayanarak sürdürülebilir afet yönetiminde atık yönetiminin yeri tartışılmıştır. Afet atık yönetimine ilişkin bilgilere ilaveten mevcut yasal mevzuat ve organizasyon yapıları hakkında da bilgiler verilmiştir.

\section{$\underline{\text { Anahtar Sözcükler }}$}

Afet Yönetimi, Afet Atık Yönetimi, Yasal Mevzuat, Çevre

\section{Waste Management in Sustainable Disaster Management}

\begin{abstract}
Disasters cause significant damage worldwide. These damages cause an environmental and economic burden in the normalization of life, restructuring and general waste collection and disposal processes. The magnitude of a disaster is related to the concepts of existing danger and vulnerability. One of the important factors affecting the vulnerability is the concept of environment. Rapid increase in population, uncontrollable urbanization, degradation of natural environment, global climate change and unpredictable hazards and risks and affect the magnitude of disasters and create significant grievances in communities. In addition, emerged disasters can cause excess amount of debris and waste depending on their severity. A sustainable disaster management system should be implemented to reduce all these damages of disasters. In the disaster management system, waste management has an important place. Waste generated as a result of disasters, disposal options of these wastes, applied disposal methods are very important in terms of environment and public health. Disaster waste management strategies are evaluated as part of waste planning and control, waste composition and quantity, waste collection and disposal options, environmental and public health legislation. If this system is not well managed, the resulting wastes can cause significant environmental and public health problems. In this review article, the role of waste management in a sustainable disaster management is discussed based on the literature. In addition to information on disaster waste management, information was also provided on existing legislation and organizational structures.
\end{abstract}

$\underline{\text { Keywords }}$

Disaster Management, Disaster Waste Management, Legislation, Environment

\section{Giriş}

Gelişmiş ve gelişmekte olan toplumlarda; karşılaşılan en büyük zorluklardan biri atıkların kontrol ve yönetimidir. Özellikle yoğun nüfuslu bölgelerde, afet sonrası ani olarak ortaya çıkan büyük miktardaki inşaat ve enkaz atıkları, sökülmüş ağaçlar, sürüklenmiş araçlar ve benzeri diğer atık türleri atıkların kontrol ve yönetimine ilaveten önemli bir yük getirmektedir. Afetler sonucu oluşan atıkların bertaraf seçenekleri ve uygulanan bertaraf yöntemleri çevre ve halk sağlığ1 açısından oldukça önemli bir yer tuttuğundan, afet zararlarını giderme çalışmalarının önemli bir kısmını atıkların toplanması oluşturmaktadır. Bu nedenle; afet sonrası meydana gelen atıkların toplanmasından önce afet yönetim sistemi içerisinde bu atıklarla ilgili olarak bazı konular tüm yönleri ile ortaya konulmuş olmalıdır. Atıkların miktarları, ortaya çıkan atıkların nereye ve nasıl taşınacağı, nasıl bertaraf edileceği, geri kazanıma ve geçici depolanmaya uygun olup olmadığı, geçici depolama tesislerinin kapasiteleri, geçici depolama tesislerinde ve geri kazanım tesislerinde kullanılacak 
olan iş makineleri kullanılacağı ve bu makinelerin kapasiteleri gibi konular afet yönetim sisteminde değerlendirilmelidir. Bu konulara ilaveten tüm bu yapılacak çalışmaların maliyeti, finansal desteği, maliyet azaltımı ve alternatif yöntemlerin ne olacağı gibi konular da afet öncesi yapılacak çalışmalarda yer almalıdır. Afet atık yönetimi ile ilgili yapılacak çalışmalar; planlama ve kontrol, işin öncelik sırası ve kaynakların yönetimi olarak sıralanabilir. Bu konuların gündeme alınarak gerekli önlemlerin alınmasında ve risk analizlerinin çıkarılmasında farklı ülkelerde ve daha önce yaşanan afetler sonrası kazanılan deneyimler ve uygulamalar faydalı olacaktır. Oluşabilecek acil durumlar ve doğal felaketlere karşı hazır olmak, bu konularla ilgili temel bilgileri toplamak ve ilgili organizasyonları oluşturmak; bu gibi sorunlarla baş etme becerisinin gelişmesini sağlamaktadır. Bu açıdan afet atık yönetimi ile ilgili yapılan literatür çalışmalarında bir hayli boşluklar bulunmaktadır. Bu literatür incelemesinin, afet atık yönetimi konusunda gelecekteki kapsamlı araştırmalar için bir çerçeve oluşturacağı öngörülmektedir.

\section{Afet Kavramı ve Büyüklüğü}

Afet kavramı; Birleşmiş Milletlerin kabul ettiği en genel tanımla "fiziksel, ekonomik ve sosyal kayıplar oluşturan, günlük yaşamı ve insan aktivitelerini durdurarak veya kesintiye uğratarak toplumları etkileyen ve yerel imkanlar ile baş edilemeyen doğal, teknolojik veya insan kaynaklı tüm olaylar” şeklinde tanımlanmaktadır (Kadığlu 2008). Bu tanıma göre bir olayın afet niteliği kazanabilmesi için olayın; can, mal, doğal çevre ve iş sürekliliğine zarar vermesi gerekir (Büyükkaracığan 2016). Afetler, toplumlarda ölüm, yaralanma gibi önemli sorunlara yol açabilirken, afet öncesi kendi kendine yetebilme kapasitesine sahip olan toplumlar afet sonrası belirli bir süre dişarıya bağımlı hale gelebilmektedirler (Odabaş 2010; Fritz 1961; Ploughman 1997; Kumar 2000).

Afet sonucu meydana gelen can ve mal kayıları, yaralanmalar, meydana gelen yapisal hasarlar, sosyal ve ekonomik kayıplar bir afetin büyüklüğünü belirler (Ergünay 2009). Bir afetin büyüklügüne etki eden birçok faktör vardır. Bu faktörler; meydana gelen olayın fiziksel büyüklüğü, kalabalık nüfusa sahip yerleşim yerlerine olan uzaklığg, bölgenin refah düzeyi, nüfus artış hızı, riskli bölgelerdeki denetimsiz şehirleşme, kontrolsüz endüstrileşme, ormanlık alanların ve doğal çevrenin bozulması veya yanlış kullanımı, eğitim eksikliği, toplumun afet olaylarına karşı önceden alabildiği koruyucu ve önleyici önlemlerin derecesi şeklinde sıralanabilir (Erkal ve Değerliyurt 2009). Olayın fiziksel büyüklüğü ve yoğun yerleşme alanlarına olan uzaklığı dışında yer alan diğer tüm faktörler insan aktivitesine bağlı faktörlerdir (Ergünay 2002). Bunlar; afetin nerede olduğunu, şiddetini ve olma sıklığını belirlediği gibi afet sırasında ve sonrasında toplumu ve çevreyi ne derecede etkilediğiyle de doğrudan ilişkilidir (Büyükkaracı̆̆an 2016).

\section{Afet Türleri}

Afetler; oluşum hızlarına ve kökenlerine göre iki ana gruba ayrılabilirler (Ergünay 2009). Oluşum hızlarına göre afetler:

a) Ani gelişen afetler: depremler, ani seller, çı̆̆ düşmeleri, yanardağ patlamaları, nükleer ve kimyasal kazalar, firtınalar ve tayfunlar

b) Yavaş gelişen afetler: küresel iklim değişimi, kuraklık, erozyon, çölleşme, salgın hastalıklar olmak üzere iki ana gruba ayrilabilirler.

Ani gelişen afetlere göre yavaş gelişen afetler oluşum hızı daha yavaş ilerlediği için zaman içerisinde koruyucu, önleyici ve risk azaltıcı önlemleri almak daha kolaydır.Afet ve Acil Durum Yönetim Merkezi tarafından kökenlerine göre afetler ise aşağıdaki gibi sınıflandırılmıştır:

a) Jeolojik doğal afetler: deprem, heyelan ve yanardă̆ patlamaları

b) Meteorolojik doğal afetler: sel, çı̆̆ fırtına, kuraklık, orman yangını, hortum

c) Teknolojik afetler: baraj patlamaları

d) İnsan kökenli afetler: yangınlar, hava, su, çevre kirlenmeleri ve ulaşım kazaları

Ergünay (2009)'a göre; bazı araştırmacılar, afetlerin bu tür gruplara ayrılmasını uygun görmemektedirler. Bunun nedenini de; tüm afetlerin aslında insan kökenli olduğunu, insanların sebep oldukları, politik, sosyal, çevresel ve ekonomik nedenlerden kaynaklandığı şeklinde açıklamaktadırlar. Aslında doğal, teknolojik ve insan kökenli afetlere bakıldığında bu afetlerin ayrımının keskin sınırlamalarla yapılamayacağı görülmektedir. Farklı kökene ait olan afetler birbirlerini etkileyerek tetiklemekte ve giderek karmaşık sonuçlar doğurmaktadır (Ergünay 2009). Örneğin, doğal çevrenin bilinçsizce bozulması, çevre kirliliği gibi faktörler kuraklık, sel, taşkın gibi çeşitli meteorolojik afetlerin meydana gelmesine yol açmaktadır. Bu afetlerin sonrasında da kıtlık veya salgın hastalıklar ortaya çıkabilmektedir.

\section{Afet Oluşumunda Çevre İle İlgili Riskler}

Yukarıda yapılan afet tanımını da dikkate alarak afet kavramı aşağıdaki eşitlikle ifade edilebilir (Kadıoğlu 2008):

Afet $=$ Tehlike $\mathrm{x}$ Zarar görebilirlik (Savunmasızlık) 
Bu eşitliğe göre afetin büyüklüğü tehlike ve toplumun savunmasızlığına bağlıdır. Toplumun tehlikeyi önceden tahmin etme, olası zararları önleme, azaltma, başa çıkma ve yaşamı normale döndürme hızı ne kadar yüksekse, tehlike ne kadar büyük olursa olsun afet o kadar küçük ölçekte kalacaktır. Bu durumun tam tersi bir durum da geçerli olabilir (Kadığlu 2008; Ergünay 2009).

Savunmasızlık kavramını da; tehlikeye maruz olan bir unsurun ya da unsurlar grubunun (insan, yapı, yerleşme birimi, kent, çevre gibi) tehlikenin meydana gelmesi halinde, görebileceği, fiziksel, sosyal, ekonomik ve çevresel kayıp ve zararların ölçüsü olarak da tanımlamak mümkündür (Ergünay 2009). Bu kavram; fiziksel, sosyal, ekonomik ve çevresel savunmasılık olarak da gruplara ayrılabilir. Çevre kavramı, toplumun savunmasızlık kavramına etki eden önemli faktörlerden birisidir. Denetimsiz şehirleşme ve endüstrileşme, ormanların ve doğal çevrenin bozulması veya yanlış kullanımı, küresel iklim değişiklikleri, öngörülemeyen tehlike ve riskler afetlerin büyüklüğünü etkilemekte ve toplumlarda mağduriyetler yaratmaktadırlar (Ergünay2009). Afet büyüklüğünü etkileyen bu faktörler aşağıda açıklanmıştır.

\subsection{Hızlı Şehirleşme ve Endüstrileşmenin Doğal Afet Riskleri Üzerine Etkileri}

Doğal afet riskleri, şehirleşme ve şehir planlama sürecinde dikkate alınması gereken önemli unsurlardan birisidir. Yerleşim yerlerinin afetler karşısında riskli hale gelmesinin temel sebeplerinden birisi bölgeler ve şehirlerarasındaki gelişmişlik düzeyi farklılıklarıdır (Dinler 2001). Büyük kentlerin sağladığı istihdam olanakları nedeniyle nüfus büyük şehirlere göç etmekte ve bu durum hızlı ve kontrolsüz şehirleşmenin önünü açmaktadır. Hızlı şehirleşme; barınma ve kamu hizmetlerinin sunumunda yetersizliklere neden olmanın yanı sıra kontrolsüz şehirleşme, gecekondulaşma gibi fiziksel görünümün ve kaynakların artan kullanımı nedeniyle ekonomik, sosyal ve çevresel açıdan zarar görülebilirliği de arttırmaktadır. Bu durum insan kökenli afetlerin meydana gelmesine ve pek çok yeşil alanın yok edilerek bina ve yollarla doldurulmasına sebep olmaktadır. Bunun sonucu olarak da toprağın su emme kapasitesi azalmakta ve yağmur akış hızları artarak sellenmelere ve su baskınlarına neden olmaktadır. Ayrıca, yerleşim yerlerinin yağmur suyu drenaj sistemlerinin yetersizliği ani su baskınlarını kaçınılmaz hale getirmektedir. Şehir yerleşme planlarının hazırlanma aşamasında, bölgenin olası klimatolojik ve hidrolojik koşulları göz önünde bulundurularak uygun arazi seçimi ve uygun inşaat usul ve esaslarının belirlenmesi sel baskını risklerinin azaltılmasında önemli bir rol oynamaktadır (Ergünay 2009; Keleş 2002).

Gecekondular, sağlıksız ve plansız şehirleşme açısından olduğu kadar afetler karşısında da birer risk unsurudurlar. Ülkemizde büyük kentlerin pek çoğu, birinci derece deprem kuşağı üzerinde yer alırken, bu şehirlerdeki gecekondu bölgelerinde yapılan inşaatlardaki kalitesizlikler, gecekondu bölgelerinin yerleştikleri alanlardaki tehlikeler, kişilerin sosyoekonomik yetersizlikleri, şehir planlanmasında arazilerin hatalı kullanımı ve yetersiz yağmur suyu drenaj hatları nedeniyle bu tür bölgeler doğal afet riskleri ile karşı karşıya kalmaktadırlar. 17 Ağustos 1999 yılında büyük bir yıkıma, can ve mal kaybına sebep olan Marmara depreminin sonuçlarından da bu durum açıç̧a görülmektedir.

Hızlı şehirleşme ve endüstrileşmenin sonucu olarak; yerleşim yerleri için planlarda mevcut tehlikelerin belirtilmiş olması, uyarılar yapılması ve deprem haritaları ile depremlerin bölgelere göre dağılımları bilimsel olarak ortaya konulmasına rağmen planların uygulanmasında bunların dikkate alınmaması, güvensiz yerleşim yerlerinin oluşmasına ve afet risklerinin artmasına neden olmaktadır. Afet yönetimi planlamasında; afet öncesi yapılması gereken hazırlık ve risk azaltımı çalışmaları yerine, afet sonrası meydana gelen hasarların ortadan kaldırılması üzerinde daha fazla çalışılmaktadır (Yilmaz 2003).

\subsection{Orman ve Doğal Çevrenin Bozulmasının Doğal Afet Riskleri Üzerine Etkileri}

Seller, su baskınları, heyelan, çığ düşmesi, erozyon gibi pek çok doğal afetin meydana geliş sebebinin ormanların ve doğal çevrenin bilinçli ya da bilinçsiz olarak bozulması sonucunda ortaya çıktığı bilinmektedir. Yerleşim alanı ve tarım toprağı elde etmek için bilinçli olarak çıkarılan orman yangınları ile ihmal ve bilinçsizlik nedeniyle çıkan yangınlar, tüm orman yangınlarının \%95'ini oluşturmaktadır. Türkiye'de yıllık ortalama 13.000 hektar orman alanı yangınlar nedeniyle kaybedilmektedir. Ormanların ve doğal bitki örtüsünün yok olması sonucu ortaya çıkan erozyon, sel ve heyelan riskini artırmaktadır. Bunun sonucunda akım hızı ve şiddeti artan yağış suları, yoğun çamur akışları ve heyelanlara yol açmaktadır. Özellikle kurak ve yarı kurak bölgelerdeki yüksek eğimler, çıplak arazi ve ani sağanak yağışlar, taşkın olaylarının ortaya çıkmasının ve büyük ölçüde can ve mal kayıplarına yol açmasının temel nedenleridir (Ergünay 2009). Ayrıca doğal çevrenin yanlış kullanımı; ekoloji dengelerinin bozulmasına, küresel ısınma problemine ve bunun sonucu olarak küresel iklim değişikliklerine, sellere, su baskınlarına, kasırgalara, kuraklık ve çölleşme gibi birçok doğal afete de neden olmaktadır.

\subsection{Küresel İklim Değişikliklerinin Doğal Afet Riskleri Üzerine Etkileri}

Yoğun insan faaliyetleri nedeniyle atmosferdeki sera gazlarının neden olduğu küresel ısınma ve iklim değişikliği yaşamın hemen hemen tüm alanlarını olumsuz yönde etkilemektedir. Küresel ısınma, sadece buzulların erimesi, deniz seviyesinin yükselmesi, iklim kuşaklarının kayması ve bu kaymaya bağlı olarak kaymaya uyum gösteremeyen flora ve faunanın yok olması gibi değişikliklere sebep olmaz. 
Küresel ısınmaya bağlı olarak şiddetli firtınalar, kasırgalar, tayfunlar, ani ve yoğun yağışlar gibi meteorolojik olaylar ve bu olaylara bağlı olarak oluşan taşkın ve sel gibi hidrolojik kökenli doğal afetler ile kuraklık ve çölleşme süreçleri gibi iklimsel kökenli doğal afetlerin şiddetinde, sıklığında ve etkinlik alanında da önemli artışlar olmaktadır (Türkeş vd. 2000).

Ülkemizdeki küresel ısınmanın etkilerinin özellikle su kaynaklarında azalma, kuraklık (kıtlık, sıcak hava dalgaları, tarımsal, kullanma ve içme amaçlı su gereksinimi vb.), ani seller (şiddetli ve ani yağmur ve yıldırımlar), deniz suyu seviyesinin yükselmesi ve bunlara bağlı ekolojik bozulmalar şeklinde olacağı belirtilmekte ve ülkemiz olası potansiyel risk grubu ülkeler arasında yer almaktadır (Türkeş vd. 2000).

Kuraklık; sosyoekonomik etkileri, sürekliliği ve çözüm zorluğu nedeniyle en tehlikeli doğal afet olarak kabul edilmektedir. Bu nedenle, suyun yönetiminde, su havzalarının ve tarım alanlarının korunması, kuraklık planlaması ve suyun yeniden kullanımının sağlanması ve sulama tekniklerinin geliştirilmesi büyük önem taşımaktadır (Türkeş vd. 2000). Ayrıca iklimdeki sıcaklık şiddetine bağlı olarak, orman yangınlarının şiddeti, etki alanı ve süresi artabilir. Yaz kuraklığındaki artışların, çölleşme süreçlerini, topraktaki tuzlanmayı ve erozyonu arttırması muhtemeldir. Küresel ısınmanın etkilerinden biri olan deniz suyu seviyesinin yükselmesine bağlı olarak da turizm ve tarım alanları durumundaki delta ve kıyı ovaları ile haliç ve ria tipi kıyılar sular altında kalabilir (Türkeş vd. 2000).

\section{Sürdürülebilir Afet Yönetimi}

Afet yönetimi; afet sonucunu doğurabilecek olayların önlenmesi veya zararlarının azaltılması için yapılması gereken çalışmaların planlanması ve uygulanması için toplumun bütün kesimlerini içine alacak şekilde koordinasyonun sağlanması, gerekli yasal düzenleme ve kurumsal yapılanmaların tamamlanması ve etkin bir uygulama sağlamak için bütün kaynakların bu doğrultuda yönetilmesi çalışmalarının tümü olarak tanımlanmaktadır (Büyükkaracığan 2016; Kadıoğlu 2008). Sürdürülebilir afet yönetiminde, toplumun çeşitli kesimleri bu süreç içinde yer almalıdır. Afet yönetimin temel özelliği, birçok kurum ve kuruluşun birlikte hazırladığı ve her birinin görev ve sorumluluklarının belirlenmiş olduğu planların koordine edilmesidir. Bu amaçla, sürdürülebilir afet yönetimini, afet öncesi ve sonrasında yapılan tüm faaliyetler dikkate alınarak; kurtarma/ilkyardım, yeniden inşa/iyileştirme, kalkınma, önleme/risk azaltma ve hazırlık aşamalarından oluşan bir döngü şeklinde ifade etmek mümkündür (Erkan 2010) (Şekil 1).

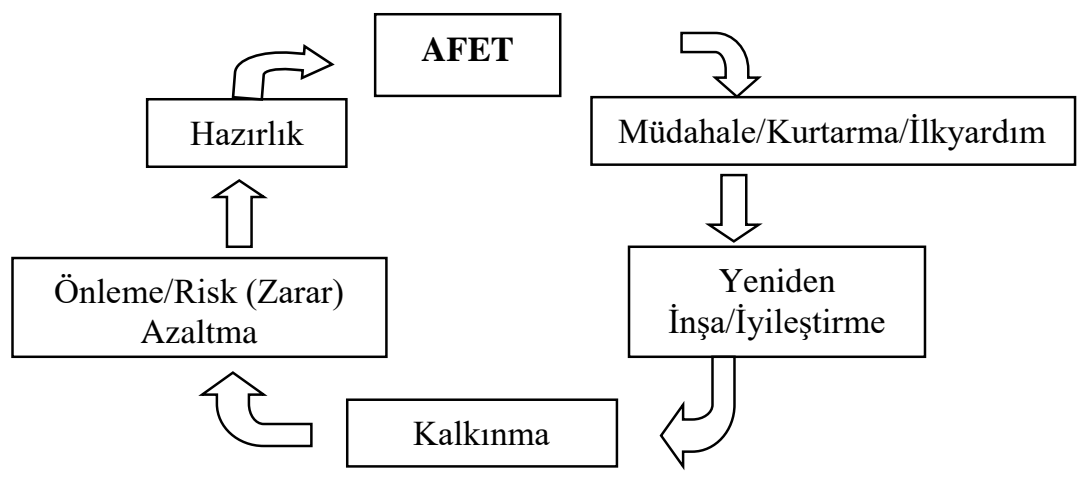

Şekil 1: Afet Yönetim Döngüsü (Erkan 2010)

Afet yönetim döngüsünü oluşturan bu bileşenler arasında sürekli bir etkileşim vardır ve birbirlerini tamamlayıcı bir fonksiyon üstlenirler. Bu bileşenler; tahmin ve erken uyarı, etki ve ihtiyaç analizi ve yeniden yapılanma gibi alt bileşenleri de kapsamaktadırlar. Bir bileşene gereken önemin verilmemesi veya sadece bir bileşene odaklanılması afet yönetiminin verimli bir şekilde yürütülememesine neden olmaktadır. Bu bileşenlerin bazen aynı anda yürütülmeleri bileşenler arasındaki ayrım zorluğuna neden olmaktadır.

Afet yönetim sisteminde, önleme/risk azaltma, hazırlık, tahmin ve erken uyarı, afetlerin anlaşılması ve etki analizi gibi afet öncesi korumaya yönelik olan çalışmalar afet öncesi (risk yönetimi); kurtarma/ilkyardım, yeniden inşa/iyileştirme gibi düzeltmeye yönelik olarak yapılan çalışmalar ise afet sonrası (kriz yönetimi) olarak adlandırmaktadırlar (Kadıŏlu 2008).

Afet öncesi aşama olan risk yönetim safhası; zararın minimize edilmesi için meydana gelebilecek afetlerden doğabilecek sonuçlara karşı önlemler alarak, zamanında, en uygun şekilde ve en etkili organizasyon ile müdahale edebilmeye hazırlanmaktır. Risk yönetimin en önemli ve ilk aşaması risk (zarar) azaltmadır. Risk azaltma; tehlikeli durum nedeni ile oluşabilecek can ve mal kayıplarını azaltmayı ya da ortadan kaldırmayı amaçlayan faaliyet ve önlemlerdir. Risk azaltma aynı zamanda, toplumu basit önlemler konusunda eğiterek kayıp ve yaralanmaları azaltmayı hedefler (Kadığlu 2008). Risk azaltma safhası, afetlerden sonra iyileştirme ve yeniden inşa safhasındaki faaliyetlerle birlikte başlar ve yeni bir faaliyet olana kadar devam eder. Bu safhada yürütülen faaliyetler ülke, bölge ve yerleşme birimi bazında olmak üzere çok geniş uygulama alanı göstermektedir. Bu safhada yapılacak çalışmalar aşağıdaki gibi sıralanabilir (Ertürkmen 2006): 
- Afet anında uygulanacak yasal mevzuatın, yapı ve deprem yönetmeliklerinin, imar mevzuatı ve alan kullanımı yönetmeliklerinin gözden geçirilmesi ve gerekiyorsa yeniden düzenlenmesi,

- Afet tehlikesi ve riskinin makro ve mikro ölçekte belirlenmesi, geliştirilmesi ve tehlike haritalarının oluşturulması,

- Deprem kayıt şebekeleri ve afet erken uyarı ve kontrol sistemlerinin kurulması ve geliştirilmesi,

- Afetlere karşı önleyici ve zarar azaltıcı mühendislik tedbirlerinin geliştirilmesi ve uygulanması

- Afet zararlarının azaltılması konusunda ilgili her kesimi kapsayan eğitim vb. faaliyetlerin yürütülmesidir.

Risk yönetimin ikinci önemli safhası olan hazırlık aşaması, acil durum ve afet halinde yetki ve sorumlulukların belirlenmesi ve kaynakların düzenlenmesini içerir. Bu aşamada tüm yönetimler acil durum/afet yönetimi görevleri için gerekli atamaları veya belirlemeleri yapmalı, İl düzeyinde "Kurtarma ve Acil Yardım Planları" hazırlanmalı, ekipman ve donanımların bakımı, tahmin ve erken uyarı sistemlerinin kullanımı, personelin eğitimi ve diğer aktiviteler sürekli güncellenmelidir (Kadıoğlu 2008; Ertürkmen 2006).

Afet sonrası kriz yönetimi aşamasında yer alan müdahale/kurtarma/ilkyardım safhası; afetin hemen sonrasında başlayan, afetin büyüklüğüne bağlı olarak en çok birkaç aylık bir süre içerisinde yapıllan faaliyetlerdir. Can ve mal kurtarma çabalarının yanı sıra bölgedeki idari birimdeki olağanüstü durumun da normale dönmesi için çalı̧̧malara başlanması gerekmektedir. Müdahale safhasında görev alacak personelin belirlenmesi, halkın uyarılması ve bilgilendirilmesi, tahliye edilmesi ve barındırılması, beslenme, ısınma ve güvenliğin sağlanması, arama kurtarma çalışmaları, ilk yardım, haber alma ve ulaşımın sağlanması, hasar tespitinin yapılması, psikolojik destek ve hatta bölge dışından talep edilecek yardımlar "müdahale" safhası kapsamındaki çalışmalardır. Bu safhada yapılan faaliyetler arasında; yangınlar, patlamalar, bulaşıcı hastalık gibi ikincil afetlerin önlenmesi için çevre sağlı̆̆ ve koruyucu hekimlik çalışmaları da yer almaktadır (Erkan 2010; Kadıŏlu 2008).

Kriz yönetim aşamasında yer alan diğer bir safha da iyileştirme safhasıdır. İyileştirme safhası yeniden inşa safhası ile birlikte yürütülmektedir. Bu safhadaki amaç; oluşması olası yeni riskleri de tespit ederek afet öncesinden daha güvenli ve gelişmiş bir yaşam alanı oluşturulması amacıyla, haberleşme, ulaşım, su, elektrik, kanalizasyon, eğitim, sosyal ve kültürel faaliyetler ile ekonomik faaliyetlerin yeniden oluşturulması, geliştirilmesi ve geçici/daimi yerleşim yerleri çalışmalarının yürütülmesine yönelik faaliyetleri içermektedir (Erkan 2010). Örneğin; 17 Ağustos-12 Kasım depremlerinde köylerde ve şehirlerde evini yapana yardım ve 4133 Sayılı Kanun'a göre afetzedelere 7269 Sayılı Kanun’un 29. maddesine göre kredi ödenmiştir (Ertürkmen 2006).

\section{Afet Atık Yönetim Stratejileri}

Afetler, doğalarına ve şiddetlerine bağlı olarak değişen fazla miktarda enkaz ve atık oluşturabilirler. Ortaya çıkan atıklar, mevcut katı atık yönetim tesislerine ilave aşırı yük getirebilir ve diğer acil müdahale ve kurtarma faaliyetlerini engelleyerek olumsuz yönde etki edebilir. Geçmişte yaşanmış olan felaketlerle ilgili yapılan çalışmalarda bazı durumlarda afet sonucu oluşan enkaz hacminin yıllık atık üretim oranlarının hacmine göre 5-15 kat daha fazla olduğu tespit edilmiștir (Brown vd. 2011; Basnayake vd. 2006; Reinhart ve McCreanor 1999). Ortaya çıkan bu enkaz ve atıklar; acil müdahale ve kurtarma çalı̧̧malarını olumsuz yönde etkilemekte ve vektör kaynaklı hastalıkların ortaya çıkmasına sebep olmaktadırlar. Ayrıca bu tür afet atıkları; su ve hava kalitesinin bozulmasına, gürültü kirliliğine, flora ve faunanın olumsuz yönde etkilenmesine, görsel kirliliğe neden olurken sosyoekonomik yönden de olumsuz etkiler yaratabilmektedirler (Petersen 2004). Avrupa Komisyonu (EC), atık yönetiminin, acil durum sonrası çevrenin rehabilitasyonunda ele alınması gereken temel konulardan biri olduğunu belirtmiștir (EC 2006). Afet atık yönetiminin hedefleri; insan hayatını ve sağlık risklerini en aza indirmek, çevresel riskleri azaltmaktır. Afet sırasında ve sonrasında oluşacak atık miktarını kontrol etmeyi amaçlayan yönetmelikler ve benzeri koruyucu önlemler, Şekil 1'de gösterildiği gibi afet yönetim döngüsünün önleme/risk azaltma aşamasında uygulamaya konulmalıdır. Atık ve enkaz yönetimi, atıkların toplanması, taşınması, yeniden kullanılması, geri dönüştürülmesi veya bertarafı afet yönetim döngüsünün müdahale/kurtarma/ilkyardım ve yeniden inşa/iyileştirme aşamalarında yer almaktadır (Karunasena vd. 2009). Afet atık yönetiminin yönetilememesi; iyileşme süresinin uzamasına ve maliyetin artmasına neden olur. Atıklara uzun süreli maruz kalma çevre ve halk sağlığı üzerinde potansiyel bir risk oluşturur (Öztürk 2017). Süreç etkin bir şekilde yürütüldüğü takdirde enkaz atıkları; geri kazanım ve yeniden inşa sürecinde değerli bir kaynak haline gelir. Bu durumda; sosyal ve ekonomik iyileşmeyi olumlu yönde etkileyen bir faktör olarak karşımıza çıkar (Brown vd. 2011). İyi bir planlama ve koordinasyon afet durumunda meydana gelebilecek aksaklıkların en aza indirilmesi için gereklidir.

Literatürde; afetler sırasında ortaya çıkan atıklar genellikle üç aşamada incelenmektedir (Kuramoto 1995; Baycan ve Petersen 2002; JEU 2010):

i) Acil müdahale gerektiren atıklar,

ii) Geri kazanılabilen atıklar,

iii) Yeniden inşa etmedir.

$\mathrm{Bu}$ üç aşama birbirinden bağımsız değildir. Ancak her afette bu aşamaların süreleri farklıdır. Genellikle, atık yönetimi açısından, acil durum aşaması, kısa vadeli eylem planı olarak tanımlanır ve halk sağlığı ve güvenliğine yönelik acil tehditlerin ortadan kaldırılmasını içermektedir. Bu aşama; atık sorunlarının tespiti, atığın karakterizasyonu ve atık haritasının oluşturulması aşamalarından oluşmaktadır. Genellikle birkaç gün ile yaklaşık iki hafta arasında sürmektedir. (URL-3 2013). 
Afetler sonucu ortaya çıkan atıklar, farklı amaçlarla kullanılabilmektedirler. Atıkların geri kazanım aşaması, afet sırasında ortaya çıkan atıkların birçoğunun yönetileceği bir aşamadır. Atık toplama, nakliye ve yeniden kullanım/geri dönüşüm faaliyetlerine yönelik lojistiği düzenleyen önemli bir aşamadır. Orta vadeli eylem olarak tanımlanmaktadır. Geçmişte yaşanan afetlerdeki deneyimlere göre geri kazanım aşaması yaklaşık 5 yıl kadar sürmektedir (URL-3 2013).

Uzun vadeli eylem planı olarak tanımlanan üçüncü aşama ise yeniden inşa aşamasıdır. Bu aşama; orta vadeli eylem planında tasarlanan yönetim projelerini ve afet atık durumunun sürekli izlenmesi ve değerlendirilmesini içeren bir aşamadır (URL-3 2013). Bu üçüncü aşama çok daha uzun bir süreçtir ve bu aşamanın sonunu tanımlamak oldukça zordur. Yeniden inşa aşaması yaklaşık 10 yıl olarak öngörülmektedir (JEU 2010).

Afet atık yönetim stratejisi; çevre ve halk sağlığı, mühendislik, toplumsal koşullar, yasal çerçeveler ve finansman temelinde atık planlama ve kontrolü, atık bileşimi, miktarı, atıkların toplanması, depolanması, taşınması, işlenmesi, yeniden kullanılması, geri kazanımı ve bertarafı ile ilgili bir disiplindir. Aşağıda atık yönetim stratejisi ile ilgili olarak ayrıntılı bilgiler sunulmuştur(Öztürk 2017; Karunasena vd. 2009).

\subsection{Atık Planlama ve Kontrolü}

Bir afet atık yönetim stratejisinin ilk adımı, bir afet sonucunda ortaya çıkan enkaz atıklarının kontrol edilmesidir. Bu amaçla enkaz oluşumunu azaltmaya yardımcı olmak için bazı önlemler alınmalıdır. Bu önlemlerden bir tanesi afet riski bulunan bölgelerde afetlere dayanıklı binaların planlanması ve yapılmasıdır (EPA 2008a). Pek çok ülke, afet enkazının oluşumunu azaltmaya yönelik önleyici tedbirleri ortaya koyan tehlike azaltma planlarını oluşturmaktadır (Karunasena vd. 2009). Örneğin; Sri Lanka'da konut sahipleri, afetlerden kaynaklanan zararlara karşı evlerini nasıl güçlendirecekleri konusunda eğitilmektedirler. Yine bir diğer atık azaltma yöntemi de atıkların geri kullanımı stratejisidir. Örneğin; Tsunamiden ağır biçimde etkilenen Endonezya gibi ülkelerde geri kazanım uygulamaları başarılı bir şekilde yönetilmektedir (EC 2006).

\subsection{Atık Bileşimi ve Miktarı}

Afetler sırasında ortaya çıkan atık türleri; bitkisel atıklar, tortu, toprak ve kaya atıkları, evsel tehlikeli atıklar, hasarlı bina ve altyapı yıkıntıları (yollar, boru şebekeleri vb.), endüstriyel ve toksik kimyasallar, araç enkazları, geri dönüştürülebilir atıklar (plastikler, metaller vb.), elektronik ve beyaz eşya atıkları, afet öncesi atık sahalarından gelen atıklar ile insan ve hayvan cesetleri şeklinde olabilir (Brown vd. 2011). Atık bileşiminde, miktarında ve yönetilebilirliğinde; çevresel yapıya (kıyı/iç/kentsel/kırsal) ve afet türüne bağlı olarak farklılıklar meydana gelmektedir (EPA 2008b). Bu duruma örnek verilecek olunursa; Katrina kasırgasında, her biri farklı bir yönetim yaklaşımı gerektiren hem kasırga hem de taşkınların oluşturduğu enkazlarla karşı karşıya kalınmıştır (Luther 2008). Bu yüzden her afet kendine özgü bir durum sergilemektedir.

Kentsel afet atıklarının en büyük bileşenini inşaat ve yıkıntı atıkları oluşturmaktadır. Atıklar içerisinde yer alan asbest, arsenikle işlem görmüş ahşaplar, alçıtaşı ve organik kirleticiler gibi bazı kimyasal ve tehlikeli maddeler potansiyel sağlık riskleri oluşturmaktadır (Dubey vd. 2007). Ayrıca afet sonrasında da çevreye atılan bozulmuş ve çürümüş yiyecekler, kullanılmış ya da tarihi geçmiş tıbbi atıklar, acil yardım gıda ambalajları gibi bazı tür atıklar oluşmaya devam eder (Ekici vd. 2009; Luther 2008). Afetlerden sonra felaketin büyüklüğünü ortaya koymak, atık tahmin tekniklerini iyileştirmek ve atık yönetim planlamasına, hazırlığına ve müdahaleye yardımcı olmak amacıyla birçok çalışma yapılmıştır (Brown vd. 2011). Tablo1'de farklı tür afetlerde ortaya çıkan atık türleri ilgili bilgiler sunulmuştur.

Tablo1: Farklı afet türlerinde ortaya çıkan atık türleri (FEMA 2007)

\begin{tabular}{|c|c|c|c|c|c|c|c|c|c|c|}
\hline & \multicolumn{10}{|c|}{ Oluşan atık türleri } \\
\hline \multirow{8}{*}{$\begin{array}{l}\text { Afet } \\
\text { türü }\end{array}$} & & $\begin{array}{l}\text { Bitkisel } \\
\text { at1klar }\end{array}$ & $\begin{array}{l}\text { İnşaat/ } \\
\text { y1kıntı } \\
\text { atıkları }\end{array}$ & $\begin{array}{l}\text { Kişisel } \\
\text { atıklar }\end{array}$ & $\begin{array}{l}\text { Tehlikeli } \\
\text { atıklar }\end{array}$ & $\begin{array}{l}\text { Evsel } \\
\text { tehlikeli } \\
\text { atıklar }\end{array}$ & $\begin{array}{l}\text { Beyaz } \\
\text { eşya }\end{array}$ & $\begin{array}{l}\text { Toprak/ } \\
\text { çamur/ } \\
\text { kum }\end{array}$ & Araçlar & $\begin{array}{l}\text { Çürümüş } \\
\text { atıklar }\end{array}$ \\
\hline & Kasırga/tayfun & $*$ & $*$ & $*$ & $*$ & $*$ & $*$ & $*$ & $*$ & $*$ \\
\hline & Tsunami & $*$ & $*$ & $*$ & $*$ & $*$ & $*$ & $*$ & $*$ & $*$ \\
\hline & Tornado & $*$ & $*$ & $*$ & $*$ & $*$ & $*$ & & $*$ & $*$ \\
\hline & Taşkınlar & $*$ & $*$ & $*$ & $*$ & $*$ & $*$ & $*$ & $*$ & $*$ \\
\hline & Depremler & & $*$ & $*$ & & $*$ & * & * & & \\
\hline & $\begin{array}{l}\text { Orman } \\
\text { yangınları }\end{array}$ & $*$ & & $*$ & & $*$ & $*$ & $*$ & & \\
\hline & Buz firtınaları & $*$ & & & & $*$ & & & & \\
\hline
\end{tabular}

Tablo 2'de ise son 15 yılda ortaya çıkan büyük ölçekli felaketlerdeki atık miktarları sunulmuştur. Afet durumunda ortaya çıkan atık miktarları afet türüne ve etkilenen yapılara bağlı olarak değişiklik göstermektedir. Afet sonucu ortaya çıkan atık miktarları kütle veya hacim olarak belirtilmektedir. Afet olaylarından sonra geriye dönük olarak meydana gelen enkaz miktarını ölçen birçok çalışma yapılmıştır. 
Bu çalışmalar, hem afet atık tahmin yöntemlerinin iyileştirilmesi hem de enkaz yönetiminin planlamasına, hazırlığına ve müdahaleye yardımcı olmak amacıyla gerçekleştirilmiştir (Brown vd. 2011). Bu tür çalışmaların çoğu Japonya'da yapılmaktadır. Örneğin; Hirayama vd. (2009), ev başına ya da birim zemin alanı başına enkaz hacmini/ağırlı̆̆ını tahmin etmeye yönelik çalışmalar yapmaktadırlar. Inoue vd. (2007), 1995 Büyük Hanshin-Awaji depreminde ortaya çıkan enkazın özgül ağırlıklarını araştırmışlardır. Chen vd. (2007) ise, Tayvan'da oluşan dört taşkın olayından sonra ortaya çıkan enkaz miktarlarını; nüfus yoğunluğu, toplam yağış ve su baskın alanı parametreleri ile ilişkilendirmişlerdir. Bu verilerden, ileride oluşabilecek taşkın atık hacimleri ile ilgili tahminlerde bulunmayı amaçlamışlardır. Ancak yapılan ve elde edilen tüm veriler afetlere özgüdür. Ayrıca afet sonrası atık miktarının/hacminin tahmininde uydu görüntüleri, hava fotoğrafçılığı ve GPS verileri de kullanılmaktadır.

Tablo2: Afetlere bağı olarak ortaya çıkan atık miktarları (Brown vd. 2011)

\begin{tabular}{lll}
\hline Yıl & Olay & Atık miktarı \\
\hline 2010 & Haiti depremi & $23-60$ milyon ton \\
2009 & İtalya-L'Aguila depremi & $1.5-3$ milyon ton \\
2008 & Çin-Sichuandepermi & 20 milyon ton \\
2005 & ABD-Hurricane kasırgası & 76 milyon m \\
2004 & ABD/Florida, Frances ve Jeanne kasırgası & 3 milyon $\mathrm{m}^{3}$ \\
2004 & Hint okyanusu Tsunami & 10 milyon $\mathrm{m}^{3}$ \\
2004 & ABD-Charley kasirgası & 2 milyon $\mathrm{m}^{3}$ \\
1999 & Türkiye-Marmara depremi & 13 milyon ton \\
1995 & Japonya-Kobe, Büyük HansinAwaji depremi & 15 milyon ton \\
\hline
\end{tabular}

\subsection{Atıkların Toplanması ve Atık Bertaraf Seçenekleri}

Afetler sonucu oluşan enkaz atıklarının ortadan kaldırılması işlemleri iki aşamada gerçekleştirilir. Bu aşamalardan birincisi yaşam ve güvenlik tehditlerini ortadan kaldırmak için ilk enkaz temizleme faaliyetleridir. İkincisi ise enkazların geri kazanımı için enkaz kaldırma faaliyetleridir. Genellikle, enkazın geri kazanım aşaması, acil erişim yolları temizlendikten sonra başlamaktadır (Karunasena vd. 2009; FEMA 2007).Toplanan enkaz atıklarının depolanması, tasnifi ve işlenmesi için geçici depolama alanlarına ihtiyaç vardır. İyi bir enkaz atık yönetimi için bu geçici alanların önceden belirlenmiş olması gerekmektedir (EPA 2008a). Atıkların geçici depolanma durumu; atıkların sınıflandırılması ve bertarafı için zaman kazandırır. Ancak uygun olmayan arazi kullanımı bu yöntem için sınırlayıcı olabilir. Örneğin; 2004 yılında Hint okyanusunda meydana gelen tsunami sonrası oyun alanları, pirinç tarlaları ve bataklıklar gibi geçici depolamaya uyun olmayan alanların bu amaçla kullanımı hem çevre ve insan sağlı̆̆ıı hem de insanların geçim kaynaklarını olumsuz yönde etkilediği iddia edilmektedir (Basnayake vd. 2006). Afet öncesinde geçici depolama alanlarının tanımlanması bu tür olumsuzlukların ortadan kalkmasını sağlayacaktır. Geçici depolama alanları; depolama, tasnif ve işleme gibi planlanan faaliyetler için erişim kolaylığını, çevreye duyarlı alanların korunmasını ve lojistik verimliliği göz önünde bulundurarak seçilmelidir (Karunasena vd. 2009).

Afet atıkları için farklı bertaraf seçenekleri mevcuttur. Afet sırasında oluşan atıkların bir bertaraf yöntemi inşaat ve yıkıntı atıklarının geri kazanımıdır. Çoğu durumda, afet atıklarının ana bileşeni inşaat ve yıkıntı atıklarıdır. Atık depolama alanlarının bulunmaması ve doğal kaynakların sınırlı olması nedeniyle; inşaat ve yıkıntı atıklarının geri kazanılması ile ilgili birçok araştırma ve geliştirme çalışmaları yapılmaktadır (Öztürk 2017; Lauritzen 1996). Geri kazanılan moloz; zemin altı malzemesi, beton agregası, çekirdek dolgusu ve geri dolgu ile arazi kazanımı gibi amaçlarla kullanılabilmektedir. Tablo3'de afetler sonucu ortaya çıkan atıkların geri kazanım sonucu kullanım alanları verilmiştir (Öztürk 2017). Geri kazanım yapılmasının yararları; kullanılan atık alanlarının ve yeniden inşada kullanılan hammadde miktarının azaltılması, geri dönüştürülmüş atıklardan gelir elde edilmesi ve yeni iş alanları yaratması şeklinde sıralanabilir (Öztürk 2017; Basnayake vd. 2005). Ancak geri kazanımda toplam maliyetler optimize edilirken; y1kım, nakliye, geri dönüşüm, boşaltma maliyetleri ve doğal malzemelerin fiyatları gibi ekonomik modeller oluşturulmalıdır (Öztürk 2017).

Tablo3: Afetler sonucu ortaya çıkan atıkların kullanım alanları (Öztürk 2017)

\begin{tabular}{ll}
\hline Atık malzeme & Kullanım Alanları \\
\hline Metaller & Çelik, demir dışı metaller \\
Kiremitler & Kil üretimi \\
Tuğlalar & Kil üretimi \\
Duvar & Kireç \\
İņaat Kerestesi & Kereste \\
Tahta Atıkları & Kompost, Enerji üretimi \\
Yeşil Atıklar & Kompost, Enerji üretimi \\
Elektrikli aletler ve kablolar & Alüminyum, bakır \\
Su tesisatı donanımı ve bakır borular & Pirinç, bronz \\
\hline
\end{tabular}


Diğer bir bertaraf yöntemi de enerji üretimi ve yakma prosesleri olarak tanımlanabilir. Ancak enerji üretiminin yüksek nakliye maliyetleri, sınırlı pazarının olması ve biyokütlenin uluslararası hareketliliğin kısıtlı olması bu yöntemi etkin kılmamaktadır. Yakma prosesinde ise tekrar kullanılabilir veya geri dönüştürülebilir maddeler ayrıldıktan sonra kalan atıklar uygun yanma koşulları altında yakılmaktadır (Asari vd. 2013). Yakma prosesi; Hint okyanusunda meydana gelen Tsunami ve Büyük Kobe depreminden sonra bir afet atık yönetim seçeneği olarak uygulanmıştır. Ancak yakmanın getirdiği olumsuz sağlık etkileri ve çevresel kaygılar ortaya çıkmıştır (Brown vd. 2011; Yepsen 2008). Yakma sonrası ortaya çıkan baca gazı mutlaka arıtılmalıdır (Asari vd. 2013). Bu durum da maliyeti arttırmaktadır.

Diğer bir bertaraf yöntemi ise arazi ıslahıdır. Marmara depremi sonrası bazı belediyeler enkazları yeni konut alanlarında ve sel riskine karşı kullanmışlardır. Ancak tehlikeli atıkların dolgu malzemesi olarak kullanılma potansiyeli kontaminasyon riskiyle ilgili kaygıları arttırmıştır (Baycan 2004). Ancak bu tehlikeli atıkların yaratabileceği kontaminasyon riskleri ilgili herhangi bir çalışma bulunmamaktadır. Ayrıca; dolgu bileşiminde tehlikeli atık kullanımı ile zaman içinde meydana gelen kontaminasyon ve/veya yapısal değişimler, dolgu malzemesinin yapısal dengesizliğine de yol açabilmektedir. Büyük Hanshin-Awaji depremi sonrası, enkaz atıklarının kıyı arazilerinin 1slahı programlarında kullanılabilmesi için enkazın yeterince temiz olmasını sağlamak üzere önemli miktarlarda ayıklama ve atık ayrımı yapılması gerektiği bildirilmiştir (Lauritzen 1998). Bu nedenle tehlikeli maddeler uygun bir arıtma prosesi oluşturuluncaya kadar geçici depolama alanlarında uygun şekilde depolanmalıdır (Asari vd. 2013).

Son olarak; atık sahalarında kalıcı depolama yöntemi de afet atıklarının bertaraf yöntemi olarak karşımıza çıkmaktadır. Birçok büyük ölçekli afetlerde oluşan atıkların hacimleri kalıcı atık saha kapasitelerini aşmaktadır. Genel atıkların içinde yer alan tehlikeli atıkların herhangi bir ayrıştırma yapılmadan depolanması çevre ve halk sağlığı açısından sorun oluşturabilmektedir.

Tablo 4'de bazı afetler sonrası uygulanan atık yönetim stratejileri verilmiştir. Tablo 4'e göre atık yönetimi için en yaygın olarak kullanılan strateji geri dönüşüm tesisleri olarak görülmektedir. Bina atıklarının geri dönüştürülmesi ve yeniden kullanılması doğal kaynakların korunmasını sağlamaktadır. Bunun yanı sıra bina atıkları afet sonrası yeniden yapılandırma için mühendislik malzemesi kaynağı olarak görülmektedir. Bu durumda; bina atıklarının yönetimi, çevresel faydaların yanı sıra ekonomik faydalar da sunmaktadır (Karunasena vd. 2009).

Tablo4: Uygulanan Atık Yönetim Stratejileri (Karunasena vd. 2009; Baycan ve Petersen 2002; de Boer ve Sanders 2004)

\begin{tabular}{|c|c|c|c|}
\hline Afet & Miktar & $\begin{array}{c}\text { Uygulanan Atık Yönetim } \\
\text { Stratejisi }\end{array}$ & Oluşan sorunlar \\
\hline $\begin{array}{l}\text { Marmara } \\
\text { depremi, Türkiye }\end{array}$ & $\begin{array}{l}13 \text { milyon } \\
\text { ton }\end{array}$ & $\begin{array}{l}\text { - Geçici depolama } \\
\text { - Geri dönüşüm } \\
\text { - Arazide depolama }\end{array}$ & $\begin{array}{l}\text { - Atıkların iki kez taşınması nedeniyle oluşan } \\
\text { yüksek taşıma maliyetleri } \\
\text { - Geri dönüşüm tesislerine gelen ilave yük } \\
\text { nedeniyle oluşan işletme sorunları } \\
\text { - Kıyı hatlarında yasal olmayan arazi } \\
\text { depolamasının yapılması }\end{array}$ \\
\hline $\begin{array}{l}\text { Kobe Depremi, } \\
\text { Japonya }\end{array}$ & $\begin{array}{l}15 \text { milyon } \\
\text { ton }\end{array}$ & $\begin{array}{l}\text { - Az oranda geri dönüşüm } \\
\text { - Çoğunlukla depolama } \\
\text { veya arazi islahı }\end{array}$ & $\begin{array}{l}\text { - Geri dönüşüm atıklarının bileşenlerine } \\
\text { ayrılması nedeniyle oluşan zaman ve maliyet } \\
\text { artışı }\end{array}$ \\
\hline Beyrut, Lübnan & 4 milyon ton & • Geri dönüşüm & $\begin{array}{l}\text { - Enkaz atıklarının "temizliğii" ile ilgili ortaya } \\
\text { çıkan sorunlar }\end{array}$ \\
\hline Kosova & $\begin{array}{l}10 \text { milyon } \\
\text { ton }\end{array}$ & $\begin{array}{l}\text { - Geri dönüşüm } \\
\text { - Depolama }\end{array}$ & - Geniş bir kırsal alanda atıkların yayılması \\
\hline
\end{tabular}

Atıklara uygulanacak bertaraf yöntemleri afet türüne bağlı olarak oluşan atık özelliğine göre karar verilmesi gereken bir durumdur. Öztürk (2017)'den alınan bilgilere göre ise; örneğin; Hugo kasırgası (1989) Charleston, yaklaşık 400.000 tonluk yeşil atık meydana getirmiştir. Bu miktardaki yeşil atık, atık depolama sahası kapasitesinin çok üzerinde bulunmuştur. $\mathrm{Bu}$ arıkların yakılması gündeme gelmiş ancak hava kirliliği riskinden dolayından reddedilmiştir. Bunun yerine tüm moloz, toprak örtüsü olarak kullanılmak üzere öğütülerek dağıtılmıştır (Öztürk 2017).

Sel molozları için uygulanan bertaraf yöntemine örnek verilecek olursa; Midwest (1993) selinden sonra molozlar atık tipine göre ayrılmışlardır. Hurdacılar aletleri, şahıslar ahşap malzemeleri toplamışlardır. Lastik atıkları ise; katı atık depolama sahalarına ya da yolda kullanılmak üzere geri dönüşüme verilmiştir. Tehlikeli atıklarda; atık yüklenici bir firma tarafindan toplanmıştır (Öztürk 2017).

Yangınlarda da oldukça fazla miktarda moloz yığını ortaya çıkmaktadır. California'da (1993), meydana gelen yangınlarda ortaya çıkan molozların bir kısmı katı atık depolama bölgesinde bertaraf edilirken, beton ve asfalt molozlarının bir kısmı dönüştürülerek yeniden kullanıma sokulmuştur (Öztürk 2017). 


\section{4. Çevre ve Halk Sağlığı}

Afetler ve çevre ayrılmaz bir bütündür. Etkili ve akılcı çevresel yönetim ve arazi kullanımı, afet olaylarının çevre üzerindeki etkilerine karşı savunmasızlığını azaltabilir. Örneğin; Hint Okyanusunda meydana gelebilecek tsunaminin etkisinin, dalgalara karşı tampon görevi gördükleri için mangrove ve mercan resiflerinin uygun şekilde korunması ve yönetimi ile azaltılabileceğini düşünülmektedir.

Ayrıca afet atık yönetimi seçenekleri ve yönetimi de bir felaketin çevresel etkisi üzerinde etkili olacaktır. Birçok afet atık yönetimi çalışmalarının temel amacı; afet atıklarının, geri dönüşüm ve tehlikeli maddelerin uygun bir şekilde bertarafı ve işlenmesi gibi yönetim seçenekleriyle çevresel etkilerini en aza indirgemektir (UNEP 2005).

Afet atık yönetimi ile ilgili halk sağlı̆̆ı ve güvenliğinin üç temel noktası bulunmaktadır. Bu noktalarda birincisi; afet durumunda haşerat ve vektör üreme alanları ile tıbbi atıklar gibi tehlikeli atıkların sağlık yönünden tehlikeleri iyi yönetilmelidir. İkinci önemli nokta; afet atık yönetiminde bertaraf seçenekleri tercih edilirken sağlık ve güvenlik riskleri göz önünde bulundurulmalıdır. Örneğin, ABD Kasırgası Andrew (1992)'den sonra, yakılan atıklardan ortaya çıkan potansiyel çevre sağlığı riskleri konusunda USEPA endişelerini dile getirmiştir. Son üçüncü önemli nokta ise; atıklar ile temas eden herkes için sağlık ve güvenlik korumasının sağlanmasıdır (Brown vd. 2011).

\subsection{Afet Atık Yönetimi İle İlgili Yasal Mevzuat}

2013 tarihli Afet ve Acil Durum Müdahale Hizmetleri Yönetmeliği’ne göre; Çevre ve Şehircilik Bakanlığı; enkaz kaldırma, alt yapı ve hasar tespit hizmet grubu ana çözüm ortağıdır. Çevre ve Şehircilik Bakanlığı;

- Afet bölgesindeki enkazın kaldırılmasında,

- Afet bölgesindeki su, kanalizasyon ve arıtma tesisi gibi hatların acil onarımının yapılarak acilen bu hizmetlerin normale dönmesini sağlamada ve

- Afet bölgesindeki, su, kanalizasyon, arıtma gibi alt yapı ve yapı stokunda meydana gelen ön hasar boyutunu en kısa sürede belirleme ve yapmaya yönelik koordinasyondan sorumludur (URL-1 2013).

Çevre ve Şehircilik Bakanlığı Atık Yönetimi Dairesi Başkanlığı tarafından, 18.03.2004 tarihinde, 25406 sayılı resmi gazetede yayımlanan Hafriyat Toprağı, İnşaat ve Yıkıntı Atıklarının Kontrolü Yönetmeliği; doğal afet sonrası meydana gelen hafriyat toprağının geçici olarak biriktirilmesi, nakliyesi, geri kazanımı, değerlendirilmesi ve nihai bertarafına ilişkin esasları kapsamaktadır (URL-4 2004).Bu yönetmeliğe göre; doğal afetler sonucu oluşan enkaz atıklarının yönetiminden, mahallin en büyük mülki amirinin başkanlı̆̆ında oluşturulacak Kriz Merkezi sorumludur. Mülki amirler, doğal afetler sonucu oluşacak olan atıkların yönetimi ile ilgili esasları belirlemekle yükümlüdürler. Bu amaçla Kriz Merkezi oluştururlar ve olası doğal afetlere karşı önceden atık yönetim planlarını yaparlar. Kriz Merkezi ise bir doğal afet durumunda meydana gelebilecek atık hacmi, atıkların ortadan kaldırılması ve nakliyesi için gerekli olacak araç, gereç ve malzeme ile bu afet atıklarının depolanabileceği uygun arazi ve alanları ilgili Yönetmelikte belirtilen esaslara göre önceden tespit etme ve gereken hazırlıkları yapmakla yükümlüdürler. Kriz Merkezi tarafindan yapılan çalışmalarla ilgili olarak Bakanlığa düzenli olarak bilgi verilmektedir. Ayrıca, doğal afetler sonucu meydana gelen enkaz ve yıkıntı atıklarının nakliye ve depolanma faaliyetleri, ilgili belediyenin sorumluluğunda belediye veya belediyenin yetkilerini devrettiği kişi ve kuruluşlar tarafindan yürütülür. Belediyeler, doğal afet atıklarının yönetimi konusunda oluşturulan Kriz Merkezi kararlarını uygulamakla yükümlüdürler. Bu yükümlülükler içinde; hafriyat toprağı, inşaat ve enkaz atıkları ile doğal afet atıklarının toplanması, geçici biriktirilmesi, nakliyesi, geri kazanımı ve nihai bertarafı ile ilgili yönetim planının hazırlanması da yer almaktadır. Belediyeler, hafriyat toprağı, inşaat ve enkaz atıklarının geri kazanım tesis alanları ile depolama alanlarının yerlerini belirlemek, kurmak veya kurdurtmak, işletmek veya işlettirmek, depolama sahası inşaatı veya işletilmesinde insan ve çevre sağlığını riske atmayacak şekilde gerekli tedbirleri almak veya aldırtmakla, toplanan inşaat ve enkaz atıklarını öncelikle altyapı çalışmalarında kullanmak veya kullandırmakla yükümlüdürler (URL-4 2004).

21 Nisan 2017 tarihinde Çevre ve Şehircilik Bakanlığı tarafından yeni gelişmelere uyum sağlanabilmesi amacı ile yıkım ve hafriyat faaliyetlerinin ve bu faaliyetler neticesinde ortaya çıkacak hafriyat toprağı ile inşaat ve yıkıntı atıklarının çevre ve insan sağlığına ve güvenliğine zarar vermeyecek şekilde yönetimine ve kontrolüne ilişkin çalışmaların veriminin ve etkinliğinin arttırılmasını sağlamak için "Yıkım İşlemleri ile Hafriyat Toprağı, İnşaat ve Yıkıntı Atıklarının Kontrolü Yönetmeliği Taslağı” hazırlanmış ve görüşlere sunulmuştur (URL-2 2017).

\section{Sonuçlar}

Afetler, geçmişte olduğu gibi gelecekte de insanlara ve çevreye yönelik yıkıcı etkilerini sürdürmeye devam edecektir. Bir afet sonrası meydana gelen can kaybı en önemli kayıp olmasına rağmen, bina ve altyapıların tahribi de ekonominin yanı sıra ekosistem için önemli bir kayıp olarak düşünülebilir. Afet sırasında yıkılan binalar ve altyapıdan kaynaklı, beton, tuğla ve kereste gibi oldukça fazla miktarda molozlar ortaya çıkmakta ve bu da toplumlara ek bir yük getirmektedir. Afetler sonucu oluşan bu tür atıkların bertaraf seçenekleri, uygulanan bertaraf yöntemleri çevre ve halk sağlığı açısından oldukça önemli bir yer tutmaktadır. Afet yönetiminin bir parçası olan afet atık yönetiminin hedefleri de insan hayatını ve sağlık risklerini en aza indirmek, çevresel riskleri azaltmak ve etkilenen topluluklara fayda sağlamaktır. 
Afet atık yönetimi; atık planlama ve kontrolü, atık bileşimi, miktarı, atıkların toplanması, depolanması, taşınması, işlenmesi, yeniden kullanılması, geri kazanımı ve bertarafı ile ilgili bir disiplindir. Bir afet atık yönetim stratejisinin ilk adımı, bir afet sonucunda ortaya çıkan enkaz atıklarının kontrol edilmesidir. Afet atıkları için farklı bertaraf seçenekleri mevcuttur. Bu bertaraf seçenekleri arasında moloz atıklarının geri kazanımı önemli bir seçenektir. Bu nedenle; moloz atıklarının geri kazanılması ile ilgili birçok araştırma ve geliştirme çalışmaları yürütülmektedir. Ancak geri kazanımda toplam maliyetler optimize edilirken; yıkım, nakliye, geri dönüşüm, boşaltma maliyetleri ve doğal malzemelerin fiyatları gibi ekonomik modeller oluşturulmalıdır (Öztürk 2017).

Diğer bertaraf yöntemleri ise enerji üretimi, yakma, arazi ıslahı ve kalıcı depolamadır. Atıklara uygulanacak bertaraf yöntemleri afet türüne bağlı olarak oluşan atık özelliğine göre karar verilmesi gereken bir durumdur. Afet atık yönetimine ilişkin gerekli yasal mevzuat ve düzenlemelerle ilgili çalışmalarda yürütülmektedir. Bu derleme çalışması kapsamında da; afet yönetimi, bu yönetimin önemli bir bileşeni olan atık yönetiminin stratejileri alt başlıkları halinde incelenmiştir.

\section{Kaynaklar}

Asari M., Sakai S., Yoshioka T., Tojo Y., Tasaki T., Takigami H., Watanabe K., (2013), Strategy for separation and treatment of disaster waste: a manual for earthquake and tsunami disaster waste management in Japan, J. Mater. Cycles Waste Manag., 15, 290-299.

Baycan F., (2004), Emergency planning for disaster waste: a proposal based on the experience of the Marmara Earthquake in Turkey, In: 2004 International Conference and Student Competition on Post-disaster Reconstruction "Planning for Reconstruction" Coventry, UK.

Baycan F., Petersen M., (2002), Disaster waste management - C\&D waste, In: Annual Conference of the International Solid Waste Association, 8-12 July, Istanbul, Turkey.

Basnayake B.F.A., Chiemchaisri C., Visvanathan C., (2006), Wastelands: clearing up after the tsunami in Sri Lanka and Thailand, Waste Manag., World., 31-38.

Basnayake B.F.A., Chiemchaisri C., Mowjood M.I.M., (2005), Solid wastes arise from the Asian tsunami disaster and their rehabilitation activities: case study of affected coastal belts in Sri Lanka and Thailand. In 10th International Waste Management and Landfill Symposium, 3-7 October, Sardinia, Italy.

Brown C., Milke M., Seville E., (2011), Disaster waste management: A review article, Waste Management, 31, $1085-1098$.

Chen J.R., Tsai H.Y., Hsu P.C., Shen C.C., (2007), Estimation of waste generation from floods, Waste Management, 27, 1717-1724.

Dubey B., Solo-Gabriele H.M., Townsend T.G., (2007), Quantities of arsenic-treated wood in demolition debris generated by Hurricane Katrina, Environ. Sci. Technol., 41, 1533-1536.

Dinler Z., (2001), Bölgesel iktisat, 6. Basım, Ekin Kitabevi Yayınları, Bursa, 499 ss.

EC, (2006), Progress report on Post Tsunami rehabilitation and reconstruction program, European Commission (EC), europa.eu/rapid/press-release_MEMO-06-507_en.pdf, [Erişim 12 Temmuz 2018].

Ekici S., Mc Entire D.A., Afedzie R., (2009), Transforming debris management: considering new Essentials, Disaster Prev. Manag., $18,511-522$

EPA, (2008a), Planning for disaster debris, United States Environmental Protection Agency (EPA), https://www.epa.gov/sites/production/files/2016-06/documents/20160629-16-p-0219.pdf, [Erişim 12 Temmuz 2018].

EPA, (2008b), Planning for natural disaster debris, In: Office of Solid Waste and Emergency Response/Office of Solid Waste, EPA530-K-08-001, https://www.epa.gov/sites/production/files/2015-08/documents/pndd.pdf, [Erişim 12 Temmuz 2018].

Ergünay O., (2002), Afete hazırlık ve afet yönetimi raporu, Türkiye Kızılay Derneği Genel Müdürlüğü Afet Operasyon Merkezi (AFOM), Ankara (Yayımlanmamıștır).

Ergünay O., (2009), Afet Yönetimi: Genel İlkeler, Tanımlar, Kavramlar, DSİ, Ankara, ss.49.

Erkal T., Değerliyurt M., (2009), Türkiye'de Afet Yönetimi, Eastern Geographical Review, 22, 147-164.

Erkan E.A., (2010), Afet yönetiminde risk azaltma ve Türkiye'de yaşanan sorunlar, Uzmanlık tezi, DPT yayın no:2812, Ankara.

Ertürkmen C., (2006), Afet Yönetimi, Ankara Üniversitesi Sosyal Bilimler Enstitüsü, Kamu Yönetimi ve Siyaset Anabilim Dalı, Yüksek Lisans Tezi, Ankara.

FEMA, (2007), Public Assistance Debris Management Guide, Federal Emergency Management Agency (FEMA), Washington, https://www.fema.gov/media-library-data/20130726-1826-25045-418/fema_325_debris_management_guide_2007.07.25.pdf, [Erişim 12 Temmuz 2018].

Fritz C.E. (1961) Disaster. In: Merton, R.K. and Nisbet, R.A.,Eds., Contemporary Social Problems, Harcourt, Braceand World, New York, 651-694.

Hirayama N., Kawata Y., Suzuki S., Harada K., (2009), Estimation procedure for potential quantity of tsunami debris on tsunami earthquake disasters. In: Sardinia 2009, 11th International Waste Management and Landfill Symposium. CISA Publisher, S. Margheritadi Pula, Cagliari, Italy.

Inoue M., Matsufuji Y., Yanase R., (2007), Waste management and counter measures of earthquake disaster in Kobe City, Japan, In: International Waste Management and Landfill Symposium, Sardinia.

Kadığlu M., (2008), Modern, Bütünleşik Afet Yönetimin Temel İlkeleri; JICA Türkiye Ofísi Yayınları No: 2, Ankara, s. 1-34.

Karunasena G., Amaratunga D., Haigh R., Lill I., (2009), Post disaster waste management strategies in developing countries: Case of Sri Lanka, International Journal of Strategic Property Management, 13, 171-190.

JEU, (2010), Joint Environmental Unit Disaster Waste Management Guidelines, Final Draft, https://www.humanitarianlibrary.org/sites/default/files/2014/02/JEUDWMPFinalDraftfordistribution.pdf, [Erişim 12 Temmuz 2018].

Keleş R., (2002), Kentleşme politikası, 7. Bask1, İmge Kitabevi, Ankara, 703ss.

Kumar G.S.J., (2000), Disaster management and social development, International Journal of Sociology and Social Policy, $20,66-81$. 
Kuramoto N., (1995), The actual state of damage and measures under taken in Hyogo prefecture, In: Earthquake Waste Symposium, 12-13 June, Osaka.

Lauritzen Erik K., (1996), Disaster Waste Management, The ISWA Yearbook, 1996/7.

Luther L.,(2008), Disaster debris removal after Hurricane Katrina: status and associated issues, Congressional Research Service, https://fas.org/sgp/crs/misc/RL33477.pdf, [Erişim 12 Temmuz 2018].

Öztürk M., (2017), Afetlerde atık yönetimi mekanizması, http://tucev.org/dosyalar/files/afetlerde-atik-yonetimi.pdf, [Erişim 12 Temmuz 2018].

Büyükkaracığan N., (2016), Türkiye'de yerel yönetimlerde kriz ve afet yönetim çalışmalarının mevzuat açısından değerlendirilmesi, Selçuk Üniversitesi Sosyal ve Teknik Araştırmalar Dergisi, 12, 195-219.

Petersen M., (2004), Restoring waste management following disasters. In: International conference on post disaster reconstruction, UK, http://citeseerx.ist.psu.edu/viewdoc/download?doi=10.1.1.523.3210\&rep=rep1\&type=pdf, [Erişim 12 Temmuz 2018].

Ploughman P., (1997), Disasters, the media and social structures: a typology of credibility hierarchy persistence based on newspaper coverage of the love canal and six other disasters, Disasters, 21, 118-137.

Reinhart D.R, McCreanor P.T., (1999), Disaster debris management Planning Tools, Report submitted to the United States Environmental Protection Agency, 33ss.

Türkeş M., Sümer U.M., Çetiner G., (2000), Küresel iklim değişikliği ve olası etkileri, Çevre Bakanlığı, Birleşmiş Milletler İklim Değişikliği Çerçeve Sözleşmesi Seminer Notları (13 Nisan 2000, İstanbul Sanayi Odası), 7-24, ÇKÖK Gn. Md., Ankara.

URL-1, (2013), Afet ve Acil Durum Müdahale Hizmetleri Yönetmeliği, Resmi Gazete Tarihi: 18.12.2013, Resmi Gazete Sayıs1: 28855, http://www.resmigazete.gov.tr/eskiler/2013/12/20131218-13-1.pdf, [Erişim 12 Temmuz 2018].

URL-2, (2017), http://cygm.csb.gov.tr/yikim-islemleri-ile-hafriyat-topragi-insaat-ve-yikinti-atiklarinin-kontrolu-yonetmeligi-taslagigoruse-acilmistir.-duyuru-256327, [Erişim 12 Temmuz 2018].

URL-3, (2013), Disaster waste management guidelines, United Nations Office for the Coordination of Humanitarian Affairs Emergency Preparedness Section, Published by the Joint UNEP/OCHA Environment Unit, Geneva, Switzerland, https://www.msb.se/Upload/English/news/Disaster_Waste_Management.pdf, [Erişim 12 Temmuz 2018].

URL-4, (2004), Hafriyat Toprağı, İş̧aat ve Yıkıntı Atıklarının Kontrolü Yönetmeliği, Resmi Gazete Tarihi: 18.03.2004, Resmi Gazete Sayıs1: 25406, http://www.mevzuat.gov.tr/Metin.Aspx?MevzuatKod=7.5.5401\&sourceXmlSearch=\&MevzuatIliski=0, [Erişim 12 Temmuz 2018].

UNEP, (2005), Environmental management and disaster preparedness: building a multi-stake holder partnership, http://www.unep.or.jp/ietc/Publications/DM/wcdr_session_report.pdf, [Erişim 12 Temmuz 2018].

Yepsen R., (2008), Generating biomass fuel from disaster debris, Biocycle, 49(7):51.

Yılmaz A., (2003), Türk Kamu Yönetiminin Sorun Alanlarından Biri Olarak Afet Yönetimi, Pegem Yayıncılık, Ankara, $115 \mathrm{ss.}$

Odabaş Z.Y., (2010), Sürdürülebilir afet yönetimi ve kadın, Ankara Üniversitesi Rektörlüğü yayınları, Ankara, 256ss. 